\title{
SMART CITY'S SUCCESS: THE IMPORTANCE OF STAKEHOLDER COLLABORATION
}

\author{
Dila Novita, S. Sos., M.Si ; Drs. Supranoto, M.Sc., Ph.D. \\ Universitas Islam ‘ 45 Bekasi, Universitas Jember \\ dilanovitapasca@gmail.com, supranoto.fisip@unej.ac.id
}

\begin{abstract}
The smart city is an effort to offer solutions to the problems and needs of urban communities efficiently and effectively, for which understanding of the application of information technology and collaboration of various stakeholders is needed. The aim of this work is to analyze the implementation of Smart City Bekasi and to understand the importance of stakeholder collaboration to gain successfully smart city. This study applied qualitative methodology by conducting content analysis for online news media, in-depth interviews to Bekasi City Government, and participant observation. The result of the study that the success of the smart city not only be able to rely on the availability of advanced information technologies but the more important is the ability of personnel to operate the technology, in addition to the necessary collaboration of all stakeholders (government, public, private) so that the vision of the city can be realized through the application of smart city. The limitation of the people of Bekasi City to the ongoing program shows the need for more massive and intensive media involvement, especially online media in disseminating information regarding smart cities.
\end{abstract}

Keywords: Collaboration; Information Technology; Smart City; Stakeholders

\section{Introduction}

Together with the increase in population, resolving urban problems can no longer be done by conventional ways, a smart city is present offering solutions to problem-solving precisely and quickly so that a city that is safe and comfortable is realized (Townsend, 2013, Goldsmith \& Crawford 2014). Smart solutions offered through the application and collaboration of city ecosystems in smart city format, by presenting smart technology to support everyday life (Nam \& Pardo, 2011, Streitz, Rocker, Prante, Van Alphen, Stenzel \& Magerkurth, 2005). In an effort to support the vision of a city, the necessary mindset of modern humans who have environmental awareness and utilization pattern of intelligent life to the fullest Technology (Gubbi, Buyya, Marusic \& Palaniswami, 2013)

Solving urban problems requires the involvement of three components: 1 . Technology; act as enablers that help accelerate the change, especially by utilizing Information and Communication Technologies is proven to change human lifestyles in the various countries are. 2. Process; each solution requires a process of change that is carried out through daily activities. 3. Humans; the most important factor as actors of the change process and those who use the technology (Yigitcanlar \& Lee, 2014, Bughin, Chui \& Manyika, 2010).

The smart city is the dream of many big cities in many countries due to it is considered effective become a solution in overcoming obstacles to government bureaucracy, creeping congestion, damage to infrastructure, waste issues, energy inefficiencies, and various other urban community problems (Termanini, 2018, Landry, 2012, Kogan \& Lee, 2014). Thus this concept must reach various sectors, such as 
improving human resources, education, health, a social, environmental component, infrastructure, improvement, energy (Newman, 1999). So not only through advanced technology utilization, but also cooperation among the community and the city government is also needed (Castells \& Cardoso, 2006).

The application of smart city requires collaboration from various parties so that the vision city could be reached (Schaffers, Komninos, Pallot, Trousse, Nilsson \& Oliveira, 2011). There are five keys to smart city development: 1) city leaders with a vision of sustainable city development and responsiveness to community needs, 2) roadmaps that clearly facilitate the preparation of focus and stages for effective investment and development, 3) integration and synergy of planning, and regulations to support planning so that consistency in the development process is realized, 4) community involvement must be done so that the programs implemented are in accordance with community needs, 5) collaboration between the government, the community, academics, the private sector, the media, and various other stakeholders is needed (Nam \& Pardo, 2011).

According to all the previous descriptions, the aim of this work is to analyze the implementation of Smart City Bekasi and to understand the importance of stakeholder collaboration to gain successfully smart city.

\section{Research Method}

This research applied a qualitative method with a case study approach by conducting in-depth interviews to the Head of Division of Public Information Management, Department of Information and Communication of Bekasi City and One Stakeholder which is included in the Smart City Council of Bekasi from the university elements. This study is also implemented a participant observation as part of the researcher's daily activities as a scholar, and most of the time in Bekasi City (Holstein \& Gubrium, 1997, Hammersley, 2018).

Moreover, content analysis (Berelson, 1952, Holsti, 1969) applied to several online media to publish information regarding the Smart City in Kota Bekasi such as infobekasi.co.id, beritasatu.com, bekasikota.go.id, kompas.com, cnnindonesia.com, dakta.com, techinasia.com, and antaranews.com. In addition, the sources are also gained from the official portal of Bekasi City Government and the Department of Information and Communication of Bekasi City.

\section{Findings And Argument}

The results of the study Convey application of smart city in Bekasi just started the initial stage since launched in late 2015, is still searching for shapes and models to suit the character and needs of the Bekasi people, so it has not been effective and massive utilizing information and communication technology. The Bekasi City Government seeks to build community civilization so that the instruments needed in smart cities are still in the process of being adjusted. Efforts have been made by 
establishing a City Transportation Council and Smart City Council. In addition, the Bekasi City Government recognized that information technology development requires large funds, thus requiring the involvement of the private sector in supporting the availability of these facilities. The synergy of various stakeholders is expected to help to realize the Smart City of Bekasi that is Advanced, Prosperous, and Social.

Category of a town called intelligent if fulfill four components: 1) collaboration, efficient, simple, and technology (Turban, Leidner, McLean, \& Wetherbe, 2008). Through the optimization of these four components, the concept of the smart city in Bekasi City can be realized, this effort is currently being carried out by the Bekasi City Government. The average population growth rate in the city of Bekasi reaches $4 \%$ per year so that it has an impact on the ability of around 13,000 government apparatuses in providing services to a total of 2.8 million residents, along with increasing community problems in line with the development of urban civilization (McMichael, 2000).

It cannot be denied that collaboration with various parties is absolutely necessary, especially between the government and society (Kooiman, 2003). Provision of technology facilities is a necessity that must involve the business world in order to be able to assist the government in facilitating the provision of smart city infrastructure that requires very expensive costs. Modern infrastructure facilitates collaboration between the three components so that it becomes a unified system regulated in information technology networks. Local government finances are insufficient to cover all of these infrastructure needs. The availability of infrastructure can create public policies that are no longer sectoral but can run in an integrated manner by utilizing technological intelligence (Hall, 1988).

Through figure 1. drawn The Garuda Smart City Model implemented in Bekasi City is based on the development of public services as part of the Bekasi Smart Concept, including 1) Governance, through regulation and strengthening of regulations, work mechanisms, and institutions. 2) Human Resources, through increasing the capacity of existing apparatus and socialization to the community so that they can be smart in managing the city. 3) Information and Communication Technology (ICT), as an enabler that must be designed appropriately according to existing characters, regions, and users, ICT can encourage to build a smart city culture (Public Service Development in the Bekasi Smart City Concept, 2015).

Figure 1. Garuda Smart City Model

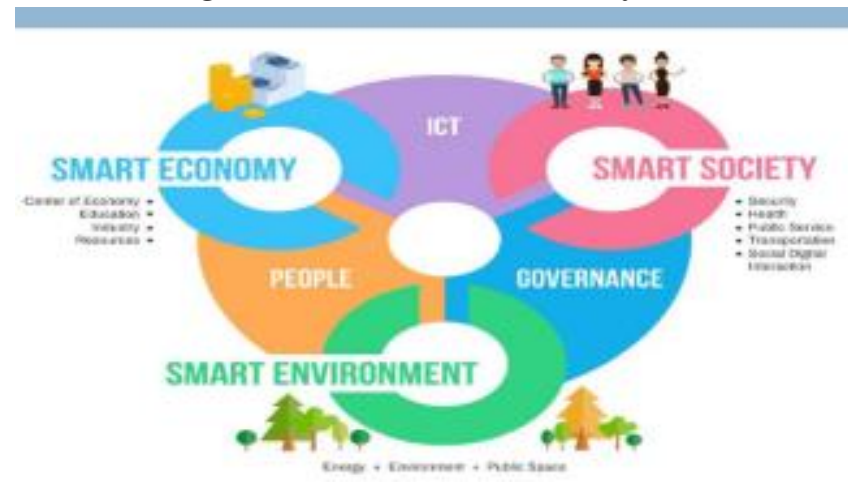

Source: Public Service Development in the Bekasi Smart City Concept, 2015 
Implementation of Bekasi Smart City

The smart city concept that is being run in Bekasi City includes a) Use of parking meter machines; began to be implemented in July 2015 in four regions (Main Road of Pondok Gede, Galaxy South Bekasi shops, South Bekasi Square, and Road of Ir . H. Djuanda East Bekasi). The parking engine used is integrated into an electric bill payment tool, banking network, refill phone balance, Public Water Company (PDAM), bill payment, and others. So it does not only function to suppress illegal parking which is the responsibility of the Department of Transportation. This shows a simple machine by utilizing technology able to function as a solution for various community needs.

Smart city concept 2) population by utilizing a National Identity Card (KTP) as a tool with various benefits, such as identification, Automatic Teller Machine (ATM), tax payment instrument, and other facilities. 3) The City Administration of Bekasi City is currently also pushing for the implementation of the smart city on garbage objects in the community by utilizing technology owned by the private sector PT. NW Industries Group to convert waste in Sumur Batu Final Disposal Site (TPA) into electricity.

In the initial installation, there were two units of waste processing machines into electricity which will be installed each with a production capacity of 2.3 Mega Watts (MW) per day from the processing of 384 tons of garbage from Bekasi City residents. Continued, adding six waste processing machines each with $2 \times 2,3 \mathrm{MW}, 2 \times 4$ MW, and 2x6 MW capacities. So that the total production of electricity from waste in the landfill Sumur Batu reached 29, 2 MW of raw materials 2,450 tons of garbage daily Bekasi City community. The concept of the smart city that exists in these objects is not only a solution to environmental hygiene problems, but also public health factors, providing employment, providing alternative energy, fertilizer production, and others.

The other smart city implementation 4) Bekasi City Government also implemented smart technology in the Public Street Lighting (PJU) system that is integrated with various services in one PJU pole object. Services that can be presented such as the installation of CCTV traffic monitors, the use of electricity saving technology on lighting devices PJU, and other devices. The efficiency of the smart lighting also applied to the PJU. Pole infrastructure is used for various things such as: installing CCTV, saving energy using a timer where the electricity supply will depend on the conditions of the environment. When it is crowded, the lights will light up brightly, but if it is quiet, the lights will dim automatically.

The smart city concept is also realized through the installation of one thousand free wifi points in all areas of the city of Bekasi. Free wifi is placed in parks because the program is integrated with processing a thousand parks. With the installation of free wifi points, Bekasi City can be connected, in the sense that public area hot spots in the form of utilization of technology can be accessed free of charge.

The method of merging public services as explained earlier is interpreted as convergence, namely the merger of several service processes to the community, which were previously separate in both planning, implementation, monitoring, and 
evaluation and determination of the technology used. In this convergence process, governance arrangements are also carried out through regulation and institutional redesign and communication media. The development of public services through the smart city concept has an impact: 1 . increasing service productivity, 2 . increasing time and cost efficiency, 3. ensuring service accountability, 4. providing service transparency, and 5. increasing Regional Original Revenue and building bags of city government development (fig . 2).

Figure 2. Bekasi Smart City (Patriot Operation Center)

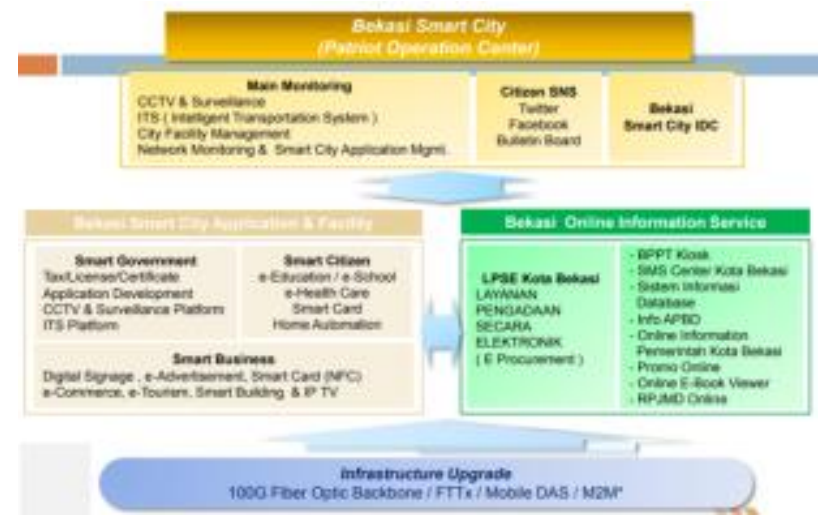

Source: Public Service Development in the Bekasi Smart City Concept, 2015

However, Bekasi City government recognizes the obstacles of in wheezing implements smart city still needs to be improved through various policies. The government bureaucracy that is still complex has made various policies carried out partially so that it confuses the public and is not systematic. This reality is inseparable from the way of thinking of bureaucrats who are still sectoral and only focus on their respective fields of work. The most obvious obstacle is seen in the Integrated Licensing Service Agency (BPPT), which still involves a number of related agencies in terms of licensing even though the packaging is one door. The difficulty is that the planning and financial rules are still partial

The introduction of information to all elements of society is a separate obstacle faced by the Bekasi City Planning Service in realizing a smart city concept. It is necessary to intensify the efforts for dissemination to the public related to the implementation of the smart city program to unify understanding and synergy as in the utilization of the program.

\section{Stakeholders Collaboration and Public Understanding}

The existence of Smart City Council formed by Government of Bekasi City is expected to be a forum for the involvement of various stakeholders in the implementation of a smart city in Bekasi. The concept of the smart city cannot be done unilaterally by the government, but it also needs the involvement of all elements of society, so that the hopes of the community can be integrated directly with the Government (Roseland, 2000). The adoption of the Smart City Council is expected to be able to encourage the acceleration of smart cities so that the City of Bekasi is able to 
enter the ranks of nine cities/regencies throughout Indonesia, and third place for implementation at the Big City level.

The Smart City Council involves several representatives, including the private sector. Budgeting for Smart City Council also did not use the Regional Income and Expenditure Budget (APBD) of Bekasi City, so that it is expected to be able to move independently. Application of smart city is also part of the implementation of the Sustainable Development Goals (SDGs) and Millennium Development Goals (MDGs) which aims to build the world community in the era of digitalization.

The smart city run by City Government of Bekasi currently only limited egovernment and it is not involving the entire community. Therefore, the presence of smart city councils is expected to be a breakthrough for people to convey their aspirations and expectations. So that collaboration between smart government and smart communities is established. The introduction of information to all elements of society is a separate obstacle faced by the Bekasi City Planning Service in realizing a smart city concept. It is necessary to intensify the efforts for dissemination to the public related to the implementation of the smart city program to unify understanding and synergy as in the utilization of the program.

The community's knowledge and understanding of the current smart city program are still very limited. Although, socialization is still underway by the Government of Bekasi city, with one of which involved a variety of media, including online media. The use of online media to disseminate information is unavoidable because, with the presence of the internet and ownership of smartphones, urban communities tend to use the tools they have in accessing information whenever and wherever they are.

Since the launch of Bekasi Smart City from 2015 until 2018, several online media actively inform programs related to the smart city. They have also presented an optimistic tone of each publishing online media that the Bekasi government and Bekasi people should make the smart city as a part of everyday life, because of the utilization of appropriate technologies impact on the ease and quality of life in the end. But the lack of information that the government conveyed to the media made the people also have limited knowledge of smart cities in the City of Bekasi. For this reason, a special program involving the media as a socialization effort must be carried out, so that people's knowledge and understanding can be better and people can feel part of the success of the smart city in the city of Bekasi.

In fact, the spread of information could no longer simply be done by word of mouth and from meeting to meeting between stakeholders, the public also needs to know immediately every smart city developments that are running. For this reason, the Bekasi City Government needs to develop a strategy that is more effective and efficient in disseminating information through online media. From the preparation and development of the program to the implementation stage, online media need to be involved, because they can be a mouthpiece for disseminating information so that the community can add to their knowledge and understanding more comprehensively. 


\section{Conclusion}

The sophistication of information technology is often regarded as a measure for the successful implementation of smart cities in urban areas, It supposed to the understanding of technology must be viewed systemically. Energy readiness, infrastructure, and especially human resources cannot be separated from the sociocultural conditions of the community where the smart city program is implemented. Bekasi City government officials must continue to adapt the technological developments in order to be able to absorb all the input, demands, and needs of the people in the city by the challenges of the times.

In addition, the success of a smart city program cannot be separated from the involvement of various parties representing the components of society. Collaboration of various stakeholders in the city of Bekasi became a necessity, especially in providing input on the preparation of smart city program strategies that were in line with the expectations of the community, helping to reduce the burden of smart city financing so that it did not become a burden on the city government through the participation of private parties who had excessive economic resources together smart city socialization needs to be done massively, to the community as the end user of the program.

In addition, people also should be adaptive to technological developments. The world of education is very significant it is expected educational institutions capable of creating human beings as powerful CERD, creative, has a strong character and wise in using technology.

\section{Acknowledgment}

Thank you to the Department of Communication and Information of Bekasi City for assistance in collecting research data.

\section{References}

Book

Castells, M., \& Cardoso, G. (Eds.). (2006). The network society: From knowledge to policy (pp. 3-23). Washington, DC: Johns Hopkins Center for Transatlantic Relations.

Goldsmith, S., \& Crawford, S. (2014). The responsive city: Engaging communities through data-smart governance. John Wiley \& Sons.

Hammersley, M. (2018). Routledge Revivals: The Dilemma of Qualitative Method (1989): Herbert Blumer and the Chicago Tradition. Routledge.

Holstein, J. A., \& Gubrium, J. F. (1997). The new language of qualitative method. New York: Oxford University Press.

Landry, C. (2012). The creative city: A toolkit for urban innovators. Routledge. McMichael, A. J. (2000). The urban environment and health in a world of increasing 
globalization: issues for developing countries. Bulletin of the World Health Organization, 78, 1117-1126.

Termanini, R. (2018). The Nano Age of Digital Immunity Infrastructure Fundamentals and Applications: The Intelligent Cyber Shield for Smart Cities. CRC Press.

Townsend, A. M. (2013). Smart cities: Big data, civic hackers, and the quest for a new utopia. WW Norton \& Company.

\section{Journals}

Berelson, B. (1952). Content analysis in communication research.

Bughin, J., Chui, M., \& Manyika, J. (2010). Clouds, big data, and smart assets: Ten techenabled business trends to watch. McKinsey Quarterly, 56(1), 75-86.

Ferraris, A., Belyaeva, Z., \& Bresciani, S. (2018). The role of universities in Smart City innovation: Multi-stakeholder integration and engagement perspectives. Journal of Business Research.

Gubbi, J., Buyya, R., Marusic, S., \& Palaniswami, M. (2013). Internet of Things (IoT): A vision, architectural elements, and future directions. Future generation computer systems, 29(7), 1645-1660.

Holsti, O. R. (1969). Content analysis for the social sciences and humanities. Reading. MA: Addison-Wesley (content analysis).

Kogan, N., \& Lee, K. J. (2014). Exploratory research on success factors and challenges of Smart City Projects. Asia Pacific Journal of Information Systems, 24(2), 141-189.

Nam, T., \& Pardo, T. A. (2011, June). Conceptualizing smart city with dimensions of technology, people, and institutions. In Proceedings of the 12th annual international digital government research conference: digital government innovation in challenging times (pp. 282-291). ACM.

Newman, P. W. (1999). Sustainability and cities: extending the metabolism model. Landscape and urban planning, 44(4), 219-226.

Roseland, M. (2000). Sustainable community development: integrating environmental, economic, and social objectives. Progress in planning, 54(2), 73-132.

Schaffers, H., Komninos, N., Pallot, M., Trousse, B., Nilsson, M., \& Oliveira, A. (2011, May). Smart cities and the future internet: Towards cooperation frameworks for open innovation. The future internet assembly (pp. 431-446). Springer, Berlin, Heidelberg.

Streitz, N. A., Rocker, C., Prante, T., Van Alphen, D., Stenzel, R., \& Magerkurth, C. (2005). Designing smart artifacts for smart environments. Computer, 38(3), 41-49. 
Turban, E., Leidner, D., McLean, E., \& Wetherbe, J. (2008). INFORMATION TECHNOLOGY FOR MANAGEMENT, (With CD). John Wiley \& Sons.

Yigitcanlar, T., \& Lee, S. H. (2014). Korean ubiquitous-eco-city: A smart-sustainable urban form or a branding hoax?. Technological Forecasting and Social Change, 89, 100-114.

\section{Website}

Pemerintah Kota Bekasi. (2015). Public Service Development in the Bekasi Smart City Concept. www.bekasikota.go.id

Dinas Informasi dan Komunikasi Kota Bekasi. (2017). Workshop e-Government and Smart City For Executive Government. https://diskominfo.bekasikota.go.id/

\section{Online Newspaper Articles}

https://infobekasi.co.id/2017/06/09/dewan-kota-cerdas-jadi-wadah-penerapanbekasi-smart-city/

http://beritabekasi.co.id/2017/06/kepala-bappeda-sebut-dewan-kota-cerdas-kotabekasi-tidak-gunakan-apbd/

https://www.bekasikota.go.id/detail/konsep-smart-city-menyelesaikan-persoalanperkotaan-dengan-cara-thinking-out-of-the-box

https://megapolitan.antaranews.com/berita/40265/transformasi-smart-city-kotabekasi

https://megapolitan.kompas.com/read/2017/07/18/21225881/wali-kota-bekasi-smart-city-di-kota-bekasi-baru-dimulai

https://www.beritasatu.com/investor/446168-6-pilar-utama-smart-city-untukbekasi.html

https://www.cnnindonesia.com/teknologi/20161130124630-185-176293/bekasi-kinisudah-smart-city

http://www.dakta.com/news/12415/kota-bekasi-masuk-daerah-gerakan-menuju100-smart-city

https://id.techinasia.com/bekasi-smart-city 